\title{
Investigations on Hysteresis-Based Current Control Techniques for Grid Connected Photovoltaic Systems
}

\author{
V. Rajini \\ Department of Electrical and Electronics Engineering, Sri Sivasubramaniya Nadar (SSN) College of Engineering, \\ Kalavakkam, India
}

Received 21 July 2014; accepted 16 December 2014

\begin{abstract}
This paper focuses on delivering an effective performance qualification (PQ) control strategy for a grid connected photovoltaic (PV) system. A PV-based distributed generation system with a capacity of 10 kilo volt amps (kVA) was connected to the utility side of a power grid operating at $415 \mathrm{~V}$. The power grid was modelled with a capacity of $100 \mathrm{kVA}, 11 \mathrm{kV}$, and $100 \mathrm{~km}$ transmission line length. The PQ control strategy was implemented with three hysteresis-based current control techniques. To overcome the drawbacks of conventional hysteresis-control techniques, adaptive tuning of the hysteresis band was carried out, and a vector-based hysteresis current control is proposed to improve the results.
\end{abstract}

Keywords: PQ control, PV-based distribution grid system, Vector-based hysteresis current control, Adaptive hysteresis current control, Conventional hysteresis current control.

\section{الفحص لتقنيات التخلفية لمتحكمات التيار لأنظمة الخلايا الكهروضوئية المتصلة}

$$
\text { بالشبكة }
$$

$$
\text { ف. راجيني }
$$

الملخص:المقالة تركز على توصيل استراتيجية متحكم PQ فعال للشبكة المتصلة بنظام الخلايا الكهروضوئية. الخلايا الكهروضوئية المعتمدة على نظام التوليد الموزع بقدرة 10 كيلو فولت أمبير يتم توصيلها بالشبكة الموحدة بفولطية 415 فولت. يتم تمثيل قدرة الشبكة بطاقة استيعابية 100 كيلو فولت أمبير و 11 كيلو فولت و خطوط نقل بطول 100 كيلو متر. استراتيجية المتحكم PQ تم بنائها بثلاثة تقنيات من متحكمات التيار بالتخلفية. للتفلب على العيوب التقليدية الموجودة بمتحكمات التيار بالتخلفية تم عمل ضبط متوائم لنطاق التخلفية وتم اقتراح متحكمات تيار بالتخلفية تعتمد على المتجهات وذلك لتحسين النتائج.

كلمات مفتاحية: متحكم PQ ، الخلايا الكهروضوئية المعتمدة على نظام التوليد الموزع ، متجها متحكمات التيار بالتخلفية ، متحكم تيار بالتخلفية متوائم ، متحكم تيار بالتخلفية تقليدي.

Corresponding author's e-mail: rajiniv@ssn.edu.in 


\section{Introduction}

The growing demand for power and an impending energy crisis have revealed the acute need for the expansion of clean energy to better meet the world's heightened power needs. Integration of solar power into the distribution grid (DG) is one of the greatest concerns in engineering. Efficient harnessing of this energy by a photovoltaic (PV) system and directly feeding it into the grid has always been the key solution to this concern. But such a system's low efficiency and poor controllability have remained the major drawbacks of a PV-based DG system (Blaabjerg et al. 2004). For a grid-connected PV system, both a voltage source pulse-width modulation (PWM) inverter and a system of closed loop power control are required. Three-phase PWM voltage source inverters have been used in high performance ac motor drives, high power factor converters, active filters, etc. (Rahim and Mekhilef 2002). In most of these applications, the magnitude of alternating current (AC) voltage is a function of the voltage across the direct current (DC) link capacitor engaged in the input side of the inverter (Kwon et al. 1998; Mohseni and Islam 2010; Vahedi et al. 2011). Regulated PWM voltage source inverters where the inner current loop determines the control over the injected power are widely employed in grid-connected DG systems in order to achieve independent control over the active and reactive power, and improve load dynamics and power quality (Chitti Babu et al. 2008; Vahedi et al. 2011).

The application of dynamic control for power injection is examined in the current study because of the varying demand for power in the utility grid due to the erratic variation in load requirements (Vahedi et al. 2011; Babu et al. 2012). Employing a performance qualification (PQ) control strategy can aid with the varying power requirements of the utility grid, and hence generate reference vectors for the inner current control loop of the voltage source PWM inverter. Effective control of the grid parameters to determine the real and reactive power references is presented and the simulation results analysed. A vector-based hysteresis control with adaptive tuning is proposed in this paper.

The basic model of a grid-connected PV system employs three different stages, including the utility grid, the DG source side control, and the three-phase pulse-width modulation voltagesource invertor (PWM-VSI). The utility grid includes a three-phase power source, the distribution line, and a three-phase resistive inductive (RL) load which varies periodically.

Figure 1 is a block diagram of a grid-connected PV system. The PV source-the solar array-is modelled mathematically through the basic parameters of a PV cell (Rahim and Mekhilef 2002). An incremental conductance-based maximum power point tracking (MPPT) algorithm was employed to obtain maximum power from the source at all stages. The output of the solar array was interfaced through a DC-DC boost converter and connected through a dc-link to the inverter. The three-phase PWM-VSI was connected to the utility grid in order to inject a three-phase current which was controlled by a PQ controller. Figure 2 shows the inverter topology connected to the grid with a filter.

The solar photovoltaic (SPV) system is modelled using the five-parameter model with equations 1-4. A detailed modelling of the SPV system can be found in references 10 and 11.

$$
\begin{aligned}
& \mathrm{I}=n_{p} I_{p h}-n_{p} I_{r s}\left\{\exp \left(\left(\frac{q}{K T A}\right) * \frac{v}{n_{s}}\right)-1\right\} \\
& \mathrm{I}_{r s}=\mathrm{I}_{r r}\left(\frac{T}{T_{r}}\right)^{3} \exp \left(\frac{q E_{G}}{K A}\left(\frac{1}{T_{r}}-\frac{1}{T}\right)\right) \\
& E_{G} E_{G}(0)-\alpha T^{2} / T+\beta \\
& I_{p h}\left(I_{s c r}+K_{i}\left[T-T_{r}\right]\right) \frac{s}{100}
\end{aligned}
$$

\section{Performance Qualification (PQ) Strategy}

The paper aims to deliver a generic $P Q$ 


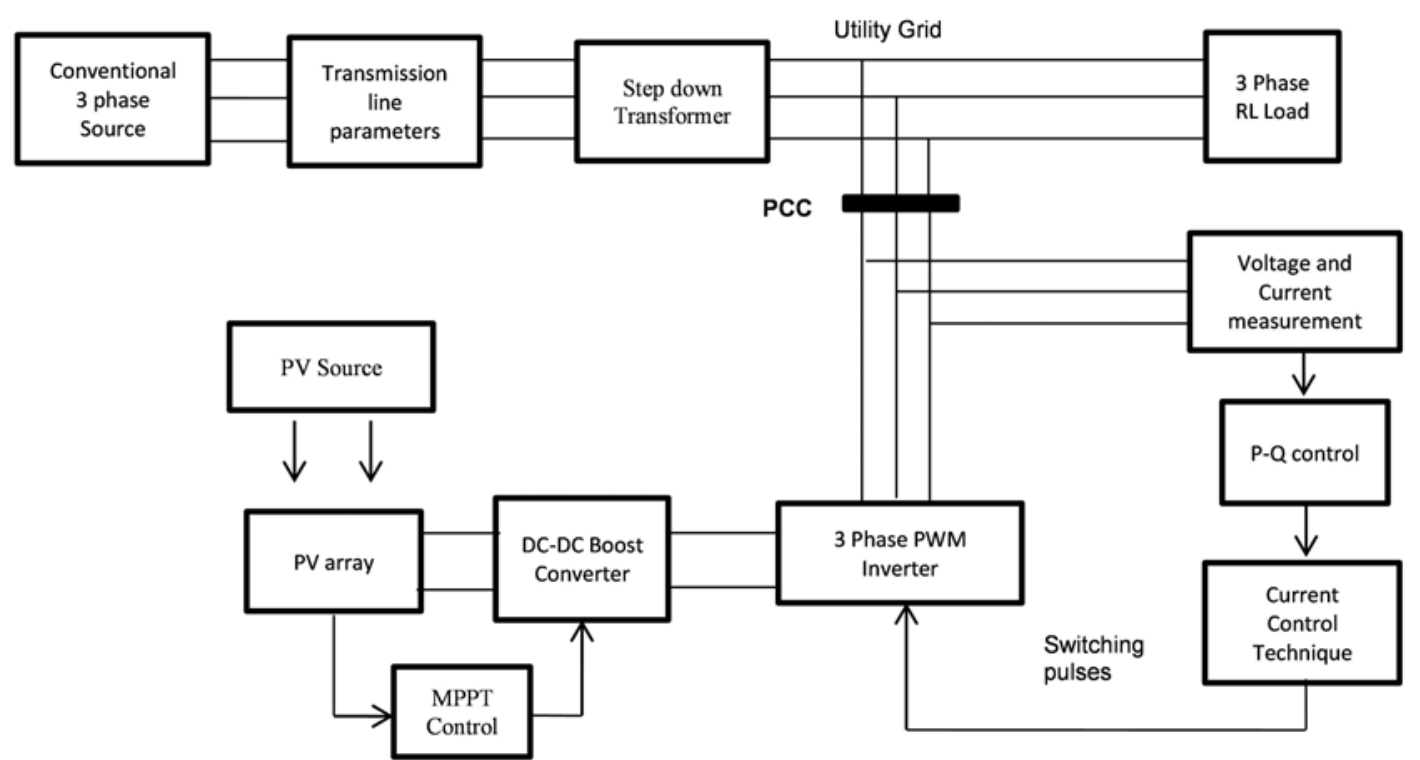

Figure 1. Block diagram of a grid-connected photovoltaic (PV) system.

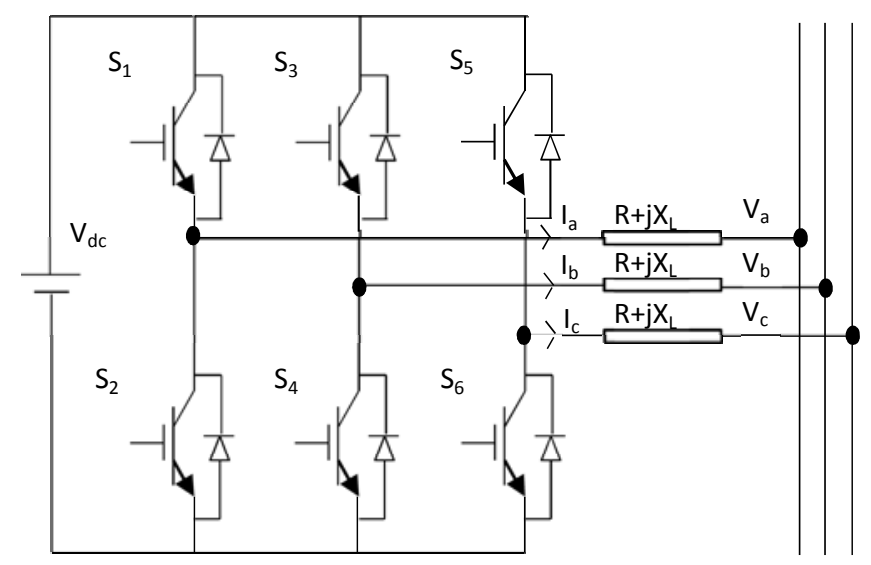

Figure 2. Inverter Topology.

control technique for any DG source. The time variables of three- phase current and voltage vectors are transformed into space vectors in a rotating reference frame (d-q) (Fig. 3). Hence, the real and reactive powers $(P$ and $Q)$ are controlled in the synchronous reference frame (d-q).

In order to determine the phase angle $(\theta)$, Clark's transformation was performed to obtain the voltage and current vectors in the stationary frame $(\alpha-\beta)$. This can be given by the Clark's transformation matrix for a three-phase system. where $\mathrm{C}^{\mathrm{T}}$ is the Clark's transformation matrix.

The current and voltage vectors are hence given by Eqns. (7) and (8). 


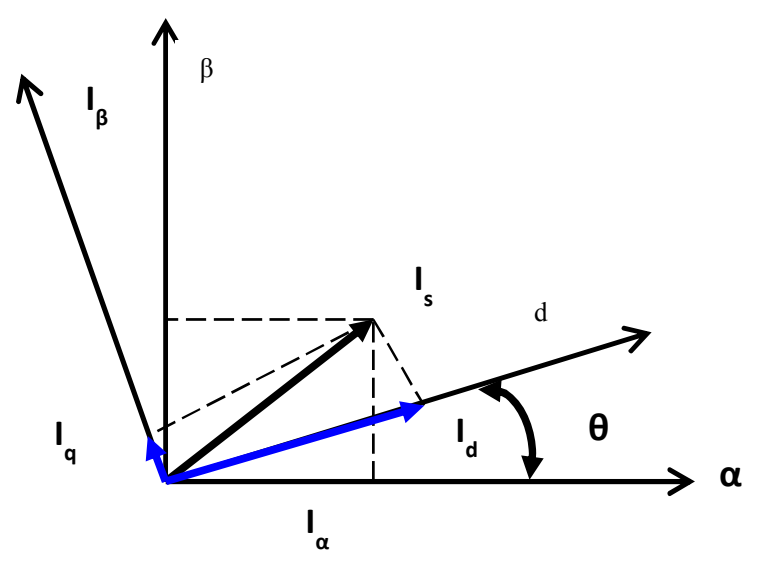

Figure 3. Stationary and rotating frames.

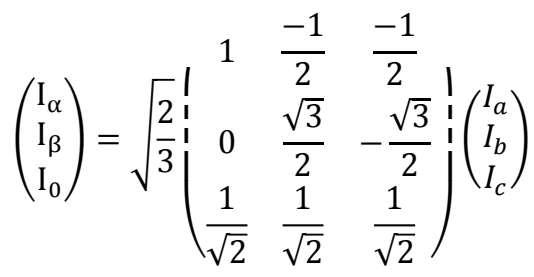

$\left(\begin{array}{c}\mathrm{I}_{\alpha} \\ \mathrm{I}_{\beta} \\ \mathrm{I}_{0}\end{array}\right)=C^{T}\left(\begin{array}{c}I_{a} \\ I_{b} \\ I_{c}\end{array}\right)$

Park's transformation was employed to convert the stationary two-phase $\left(i_{\alpha}, i_{\beta}\right)$ system into a rotating $\left(i_{d}, i_{q}\right)$ system using the unit vector angle (e) (Brod and Novotny 1985) as follows:

$$
\left(\begin{array}{l}
I_{d} \\
I_{q}
\end{array}\right)=\left(\begin{array}{rr}
\cos \theta & \sin \theta \\
-\cos \theta & \sin \theta
\end{array}\right)\left(\begin{array}{l}
I_{\alpha} \\
I_{\beta}
\end{array}\right)
$$

Using the same transformation, the voltage vectors $\left(\mathrm{V}_{\mathrm{d}}\right)$ and $\mathrm{V}_{\mathrm{q}}$ were obtained using Eqn. (8).

$\left(\begin{array}{l}V_{d} \\ V_{q}\end{array}\right)=\left(\begin{array}{rr}\cos \theta & \sin \theta \\ -\cos \theta & \sin \theta\end{array}\right)\left(\begin{array}{l}V_{\alpha} \\ V_{\beta}\end{array}\right)$

The real and reactive powers are given by Eqns. (9), (10) and (11).

$$
\begin{gathered}
P_{\text {ins }}=V_{d} I_{d}+V_{q} I_{q} \\
Q_{\text {ins }}=V_{q} I_{d}-V_{d} I_{q} \\
\left(\begin{array}{c}
P_{\text {ins }} \\
Q_{\text {ins }}
\end{array}\right)=\left(\begin{array}{cc}
V_{d} & V_{q} \\
-V_{q} & V_{d}
\end{array}\right)\left(\begin{array}{l}
I_{d} \\
I_{q}
\end{array}\right)
\end{gathered}
$$

The d-axis of the synchronous frame is aligned to rotate with the voltage vector $\left(V_{d}\right)$ and, correspondingly, the value of $\mathrm{V}_{\mathrm{q}}$ becomes zero.

Hence, the power Eqns. (9) and (10) can be rewritten as Eqns. (12) and (13).

$$
\begin{aligned}
& P_{\text {ins }}=V_{d} I_{d} \\
& Q_{\text {ins }}=-V_{d} I_{q}
\end{aligned}
$$

The value of $\mathrm{V}_{\mathrm{d}}$ corresponds to the voltage magnitude, which is a constant. Hence, precise control of the real and reactive powers to be injected can be achieved by controlling the magnitudes of $\mathrm{I}_{\mathrm{d}}$ and $\mathrm{I}_{\mathrm{q}}$. Two different constants, $\mathrm{K}_{\mathrm{P}}$ and $\mathrm{K}_{\mathrm{Q}}$, are considered such that the reference current vectors along the direct and quadrature axes are given by Eqns. (14) and (15),

$$
\begin{aligned}
& I_{\text {dref }}=K_{p} * I_{d} \\
& I_{\text {qref }}=K_{q} * I_{q}
\end{aligned}
$$

where $K_{p}$ and $K_{q}$ are the real and reactive power coefficients of the PV source, to be tuned in accordance with the real and reactive power demands, respectively.

By performing suitable inverse transformations, the above current reference variables are transformed to the $\mathrm{a}, \mathrm{b}, \mathrm{c}$ reference frame $\left(\mathrm{I}_{\text {aref }}, \mathrm{I}_{\mathrm{bref}}\right.$, $\mathrm{I}_{\text {cref }}$ ), and are used in the inner current control loop in order to generate the PWM pulses for the VSI.

The PQ control system can be so defined in order to deliver preferred ratios or desired values of real power $\left(\mathrm{P}_{\mathrm{i}}\right)$ and reactive power $\left(\mathrm{Q}_{\mathrm{i}}\right)$. In the case of a PV-based DG source of maximum capacity $\left(\mathrm{P}_{\mathrm{pv}}\right)$, the values of $\mathrm{K}_{\mathrm{p}}$ and $\mathrm{K}_{\mathrm{q}}$ are selected so that the total power conservation stays inviolate.

This can be ensured by following Eqn. (16).

$$
P_{p v} \leq \sqrt{P_{i}^{2}+Q_{i}^{2}}
$$

\section{Current Control}

The control of the inverter current by using the generated three-phase reference wave is employed for the calculated injection of power into the utility grid. 


\subsection{Conventional hysteresis Current Contro- ller}

A conventional HCC technique is preferred for its dynamic performance and ease in implementation. In this technique, an error signal is generated by direct comparison of the inverter current with the reference current value (Fig. 4). The switching pulses are so generated that the current error is kept within a predefined hysteresis band. This method aids the control of switches in an inverter by asynchronously varying the current through the load so that it tracks a reference current signal.

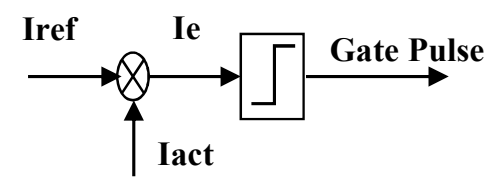

Figure 4. Gate Pulse Generation

But one major drawback of this technique is the occurrence of a high switching frequency at a lower modulation index due to a lack of coordination between three-phase hysteresis comparators (Esram and Chapman 2007). Hysteresis band violations of up to twice the bandwidth are also prone to occur. One of the much squared solutions for this problem is the use of a dual hysteresis band wherein there are two bandwidths: $\delta$ and $\delta+\Delta \delta$, such that $\Delta \delta<\delta$. This method provides a modest constructive effect in case of transients and peak overshoots. Figure 5 shows the error band region.

\subsection{Adaptive bandwidth hysteresis current control (HCC)}

Since the switching frequency in the HCC technique depends on the rate of change of the line current, it varies with the inverter current waveform $\left(I_{c}\right)$. This current also varies with the line inductance $(\mathrm{L})$ and the dc link voltage $\left(\mathrm{V}_{\mathrm{dc}}\right)$.

The bandwidth of the hysteresis band determines the tolerance of current error. Thus,

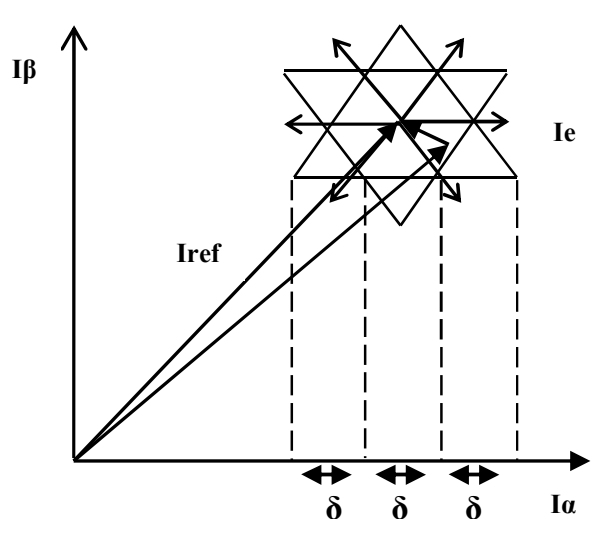

Figure 5. The error band region for conventional hysteresis current control (HCC).

the bandwidth determines the rate at which the inverter current gets switched within the hysteresis band and, hence, the switching frequency $\left(f_{s}\right)$. It can be concluded that the relation between the bandwidth and switching frequency is:

$\delta \alpha^{1} / f_{s}$

Even though the increase in switching frequency $\left(f_{s}\right)$ can improve the inverter current $\left(I_{c}\right)$, it augments the switching losses in the system, which is undesirable. Therefore, the bandwidth $(\delta)$ is selected to balance the switching losses, switching frequency $\left(\mathrm{f}_{\mathrm{s}}\right)$, and inverter current $\left(\mathrm{I}_{\mathrm{c}}\right)$.

In order to adaptively tune the bandwidth $(\delta)$, the fact that the switching frequency $\left(f_{s}\right)$ is a function of the rate of change of the line current $\left(\frac{d I_{l}}{d t}\right)$ must be considered. Thus, in a switching condition where the switch on time is $t_{\text {on }}$ and the switch off time is $t_{\text {off, }}$ the time period (T) and switching frequency $\left(\mathrm{f}_{\mathrm{s}}\right)$ are given by:

$$
1 / f_{s}=T=t_{o n}+t_{o f f}
$$

The switching of voltage and the line current $\left(\mathrm{I}_{1}\right)$ for one of the phases at the switching frequency mentioned in Eqn. (18) is illustrated below: 


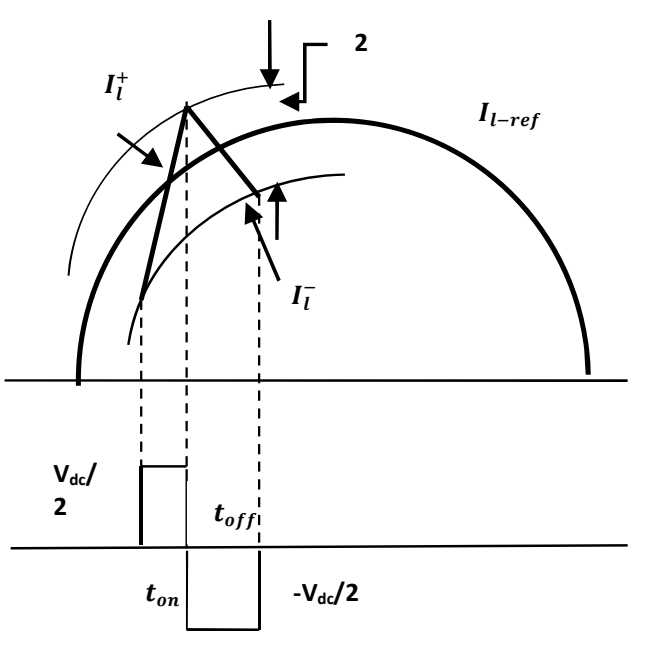

Figure 6. Switching of inverter line current within the hysteresis band.

Figure 6 is analysed in order to determine the adaptive tuning of the hysteresis bandwidth (Vahedi et al. 2011). Considering the differential rise and fall in line currents, the line inductance $(\mathrm{L})$, phase voltage $\left(\mathrm{V}_{\mathrm{ph}}\right)$ and dc input voltage $\left(\mathrm{V}_{\mathrm{dc}}\right)$ are as follows:

$d I_{l}^{+}=\frac{1}{L}\left(V_{d c} / 2-V_{p h}\right)$

$d I_{l}^{-}=\frac{1}{L}\left(-V_{p h}-V_{d c / 2}\right)$

By approximating values in Fig. 7 , the equations of the bandwidth are as follows:

$$
\begin{aligned}
& 2 \delta=\left(\frac{d I_{l}^{+}}{d t}-\frac{d I_{l-r e f}}{d t}\right) t_{o n} \\
& 2 \delta=\left(\frac{d I_{l-r e f}}{d t}-\frac{d I_{l}^{-}}{d t}\right) t_{o f f}
\end{aligned}
$$

Thus, by subtracting Eqn. (21) from (22), Eqn. (23) can be derived:

$$
\begin{gathered}
\left(\frac{d I_{l}^{+}}{d t}\right) t_{o n}+\left(\frac{d I_{l}^{-}}{d t}\right) t_{o f f}=\frac{d I_{l-r e f}}{d t}\left(t_{o n}+t_{o f f}\right) \\
\left(\frac{d I_{l}^{+}}{d t}\right) t_{o n}+\left(\frac{d I_{l}^{-}}{d t}\right) t_{o f f} \\
=\frac{d I l-r_{r e f}}{d t}\left(\frac{1}{f_{s}}\right)
\end{gathered}
$$

By adding Eqns. (21) and (22), the following is derived:

$$
\begin{gathered}
4 \delta=\left(-\frac{d I_{l-r e f}}{d t}\right)\left(t_{o n}-t_{o f f}\right)+\frac{d I_{l}^{+}}{d t}\left(t_{o n}\right) \\
-\frac{d I_{l}^{-}}{d t}\left(t_{o f f}\right)
\end{gathered}
$$

By analysing Eqns. (19), (20), (23), and (24), bandwidth $(\delta)$ can be represented as

$$
\begin{aligned}
\delta=\frac{1}{f_{s}}\left(\frac { 1 } { 2 L } \left(\frac{V_{d c}}{4}-\right.\right. & \left.V_{p h}{ }^{2}\right) \\
& \left.+\frac{1}{V_{d c}} \frac{d I_{l-r e f}}{d t}\left(\frac{L}{2} \frac{d I_{l-r e f}}{d t}+V_{p h}\right)\right)
\end{aligned}
$$

\subsection{Vector-based Hysteresis Current Control (HCC)}

The selection of optimum bandwidth $(\delta)$ was carried out in the case of the adaptive HCC technique. But this technique carries a prime disadvantage of exhibiting high switching frequencies at the zero crossing points of the reference current. Even though this approach yields an almost fixed switching frequency and minimizes inverter current oscillations, this improved performance is usually obtained at the expense of extra signal processing and control complexity requirements, which compromises the simplicity of conventional HCCs (Esram and Chapman 2007). Moreover, we may observe stability problems and limited transient performance in these adaptive tuning techniques.

As an alternate to achieving reduced switching frequencies, vector-based HCC techniques can be used. Optimal vector-based methods systematically select zero and non-zero voltage vectors to follow the reference current vector, thereby significantly reducing the inverter switching frequency.

A vector-based HCC that employs two levels of hysteresis comparators of bandwidths $\delta$ and $\delta+\Delta \delta$, to generate an optimal switching pattern that restricts the current error vector within a hexagonal tolerance region, is discussed. 
Table 1: Switching table for vector HCC.

\begin{tabular}{|c|c|c|c|c|c|c|c|c|}
\hline 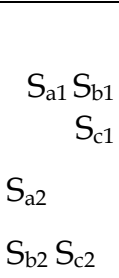 & 000 & 001 & 010 & 100 & 011 & 101 & 110 & 111 \\
\hline 100 & $\mathrm{~V}_{0}{ }^{1}$ & $\mathrm{~V}_{0} 1$ & $\mathrm{~V}_{0}{ }^{1}$ & $\mathrm{~V}_{1}$ & $\mathrm{~V}_{0} 1$ & $\mathrm{~V}_{6}$ & $\mathrm{~V}_{2}$ & $\mathrm{~V}_{0}{ }^{1}$ \\
\hline 110 & $\mathrm{~V}_{0}{ }^{0}$ & $\mathrm{~V}_{0}{ }^{0}$ & $\mathrm{~V}_{3}$ & $\mathrm{~V}_{1}$ & $\mathrm{~V}_{0}{ }^{0}$ & $\mathrm{~V}_{0}{ }^{0}$ & $\mathrm{~V}_{2}$ & $\mathrm{~V}_{0}{ }^{0}$ \\
\hline 010 & $\mathrm{~V}_{0}{ }^{1}$ & $\mathrm{~V}_{0} 1$ & $\mathrm{~V}_{3}$ & $\mathrm{~V}_{0} 1$ & $\mathrm{~V}_{4}$ & $\mathrm{~V}_{0}{ }^{1}$ & $\mathrm{~V}_{2}$ & $\mathrm{~V}_{0}{ }^{1}$ \\
\hline 011 & $\mathrm{~V}_{0}{ }^{0}$ & $\mathrm{~V}_{5}$ & $\mathrm{~V}_{3}$ & $\mathrm{~V}_{0}{ }^{0}$ & $\mathrm{~V}_{4}$ & $\mathrm{~V}_{0}{ }^{0}$ & $\mathrm{~V}_{0}{ }^{0}$ & $\mathrm{~V}_{0}{ }^{0}$ \\
\hline 001 & $\mathrm{~V}_{0}{ }^{1}$ & $\mathrm{~V}_{5}$ & $\mathrm{~V}_{0}{ }^{1}$ & $\mathrm{~V}_{0}{ }^{1}$ & $\mathrm{~V}_{4}$ & $\mathrm{~V}_{6}$ & $\mathrm{~V}_{0}{ }^{1}$ & $\mathrm{~V}_{0}{ }^{1}$ \\
\hline 101 & $\mathrm{~V}_{0}{ }^{0}$ & $\mathrm{~V}_{5}$ & $\mathrm{~V}_{0}{ }^{0}$ & $\mathrm{~V}_{1}$ & $\mathrm{~V}_{0}{ }^{0}$ & $\mathrm{~V}_{6}$ & $\mathrm{~V}_{0}{ }^{0}$ & $\mathrm{~V}_{0}{ }^{0}$ \\
\hline
\end{tabular}

This technique retains the simplicity and ease of implementation showcased by the conventional HCC. Furthermore, it offers a considerably reduced switching frequency and inverter current oscillations, thereby exhibiting improved transient and steady state performance.

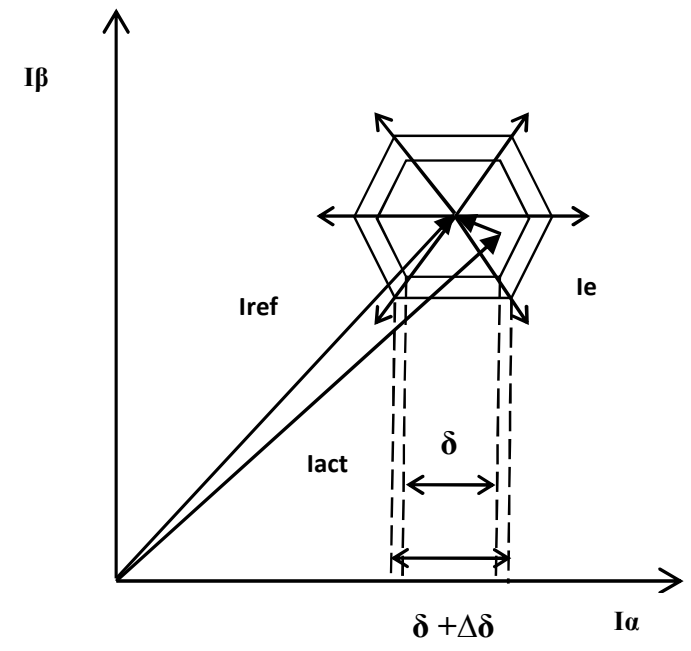

Figure 7. Error band region for vector hysteresis current control (HCC).

In order to understand the theory behind vector-based HCC schemes, an understanding of the basic voltage equations of the three phases in case of a standard inverter topology is necessary (Fig. 2).

$$
\begin{gathered}
\frac{d I_{a}}{d t}=\frac{1}{3 L}\left(2\left(V_{a}-e_{a}\right)-\left(V_{b}-e_{b}\right)-\left(V_{c}-e_{c}\right)\right) \\
-\frac{R}{L}\left(I_{a}\right) \\
\begin{aligned}
\frac{d I_{b}}{d t}=\frac{1}{3 L}\left(2 \left(V_{b}-\right.\right. & \left.\left.e_{a}\right)-\left(V_{a}-e_{b}\right)-\left(V_{c}-e_{c}\right)\right) \\
& -\frac{R}{L}\left(I_{b}\right)
\end{aligned} \\
\begin{aligned}
\frac{d I_{c}}{d t}=\frac{1}{3 L}\left(2 \left(V_{c}-\right.\right. & \left.\left.e_{a}\right)-\left(V_{b}-e_{b}\right)-\left(V_{a}-e_{c}\right)\right) \\
& -\frac{R}{L}\left(I_{c}\right)
\end{aligned}
\end{gathered}
$$

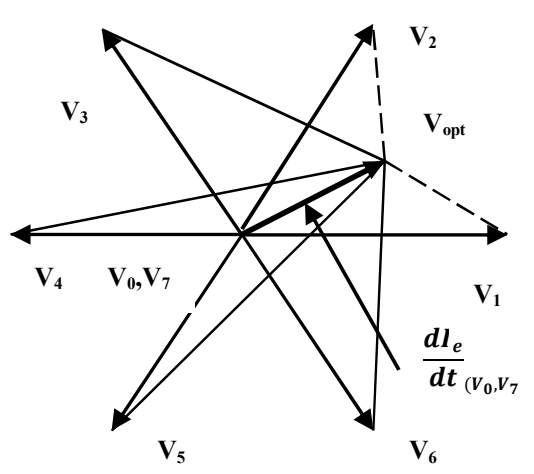

Figure 8. Tracking current error. 
The vector form of the above equations based on Clark's transformation can be given as

$\frac{d I_{a c t}}{d t}=\frac{1}{L}\left(V_{n}-e_{o}\right)-\frac{R}{L}\left(I_{a c t}\right)$

where $V_{n}$ is the output voltage vector and $e_{o}$ is the vector notation of back-electromagnetic field (emf) (Kwon et al. 1998; Mohseni and Islam, 2010). The current error can be noted as the difference between the reference and the actual values of current.

$I_{e}=I_{r e f}-I_{a c t}$

Using Eqns. (27) and (28), we can denote the derivative of error current as follows:

$L \frac{d I_{e}}{d t}+R I_{e}=L \frac{d I_{r e f}}{d t}+R I_{r e f}-\left(V_{n}-e_{o}\right)$

By eliminating the R term in equation (29), the equation for the voltage vector corresponding to the optimal switching state, such that the error current vector $\mathrm{I}_{\mathrm{e}}$ is zero, results.

$V_{o p t}=e_{o}+L \frac{d I_{r e f}}{d t}$

Equations (29) and (30) denote the derivative of the current error vector (Fig. 9). This derivative can be written as

$\frac{d I_{e}}{d t}=V_{o p t}-V_{n}$

In the case of steady state conditions, vectorbased HCC techniques usually follow control strategies to apply voltage vectors such that the tracking error is kept minimal. In Figure 8, where the optimal voltage vector lies in sector 1 , of the six non-zero and two zero vectors (Vectors $V_{0}-V_{7}$ ) (Fig. 9). the switching states corresponding to the two zero vectors and the adjacent non zero vectors $\left(\mathrm{V}_{1}\right.$ and $\left.\mathrm{V}_{2}\right)$ are the best to be applied. In contrast, during transient conditions it may be necessary to switch back the actual current $\mathrm{I}_{\text {act }}$ within the hysteresis band as quickly as possible irrespective of the tracking error value. The switching table for this technique is given in Table 1.

\section{Simulation Results}

The PQ control strategy is employed using the three current control techniques, in a three-phase $415 \mathrm{~V}$ system, rated $11 \mathrm{kV}$ at the generation end and transmission lines of length $100 \mathrm{~km}$. A resistor-capacitor circuit (RC) filter is designed to eliminate a band of harmonics at the inverter end to improve power quality. Figure 10 represents the phase voltage at the point of common coupling $\left(230 \mathrm{~V}_{\text {rms }}\right)$.

To illustrate the effect of the proposed controller, the load power, power supplied by the grid, and that generated by SPOV are varied and the details of variations are given in Table 2 . When the real power demand is 8000 Watts $(\mathrm{W})$, a peak current of $29.55 \mathrm{amps}$ (A) is supplied to the load out of which 14.49 A peak comes from the grid. When the real power demand changes to $16,000 \mathrm{~W}$ as indicated in Table 2, a peak current of $49 \mathrm{~A}$ is supplied to the load out of which $43 \mathrm{~A}$ comes from the grid. Both these current wave forms are given in Figs. 11(a) and (b). Similarly, the power demand and the power delivered by the main grid are shown in the Figs. 12(a) and (b). The sum of the power delivered by the main grid and DG source equals the power demand.

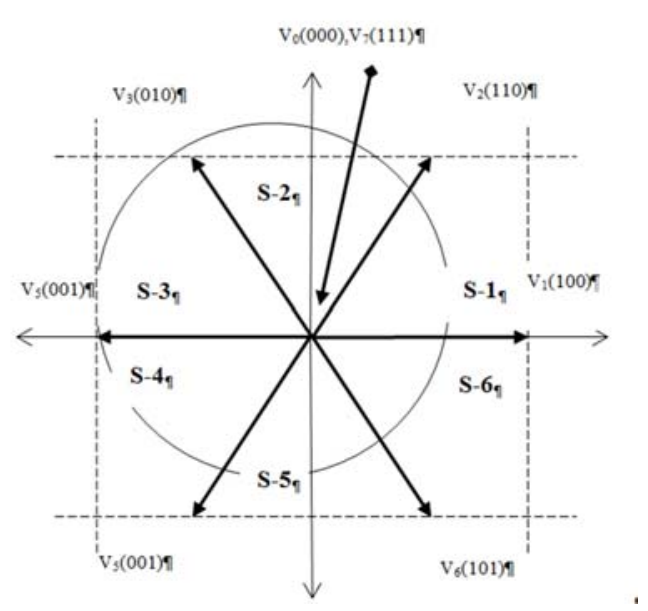

Figure 9. Space vector representation.

The load is rated to demand $8000 \mathrm{~W}$ of real power and 12,000 volts-amperes reactive (VAR) of reactive power for the time period of 0-0.1 s. An additional load is connected to the system at $0.1 \mathrm{~s}$, so that the demand rises to $16,000 \mathrm{~W}$ and 24,000 VAR for the time period 0.1-0.2 s. Hence the PQ controller (section 2) allows the DG system to inject $8,000 \mathrm{~W}$ of real power and 6,000 VAR of 
reactive power for $0-0.1 \mathrm{~s}\left(\mathrm{~K}_{\mathrm{P}}=1 ; \mathrm{K}_{\mathrm{Q}}=0.5\right)$. Once the demand rises, the controller allows the system to deliver its total capacity $(10,000 \mathrm{~W})$ as real power $\left(\mathrm{K}_{\mathrm{P}}=0.625 ; \mathrm{K}_{\mathrm{Q}}=0\right)$.

Table 2. Power Allocation.

\begin{tabular}{lcc}
\hline Periods/Parameters & $\mathbf{0 - 0 . 1}$ & $\mathbf{0 . 1 - 0 . 2}$ \\
\hline $\mathrm{P}_{\mathrm{L}}(\mathrm{W})$ & 8000 & 16000 \\
$\mathrm{Q}_{\mathrm{L}}(\mathrm{VAR})$ & 12000 & 24000 \\
$\mathrm{P}_{\mathrm{i}}(\mathrm{W})$ & 6000 & 10000 \\
$\mathrm{Q}_{\mathrm{i}}(\mathrm{VAR})$ & 6000 & 0 \\
$\mathrm{P}_{\mathrm{G}}(\mathrm{W})$ & 2000 & 6000 \\
$\mathrm{Q}_{\mathrm{G}}(\mathrm{VAR})$ & 6000 & 24000 \\
$\mathrm{~K}_{\mathrm{P}}$ & 1 & 0.625 \\
\hline $\mathrm{K}_{\mathrm{Q}}$ & 0.5 & 0 \\
\hline
\end{tabular}

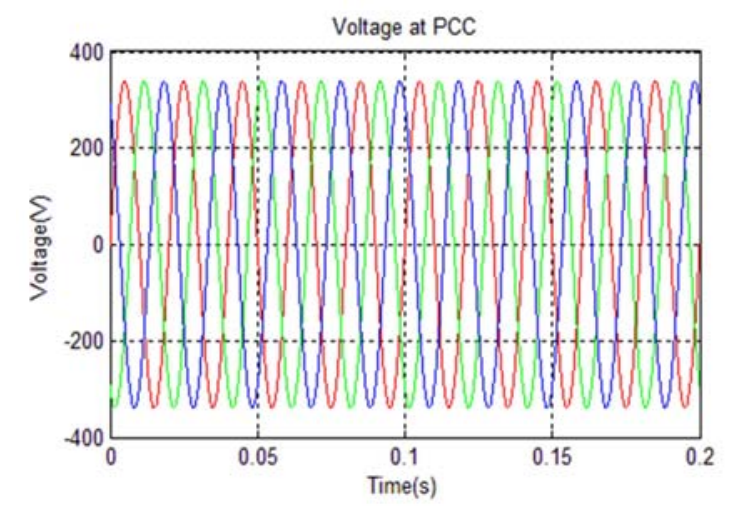

Figure 10. Voltage at the point of common coup ling.

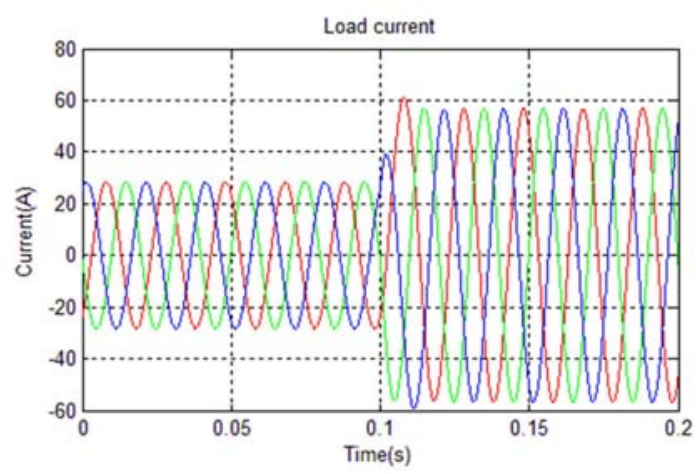

Figure 11(a). Load current required.

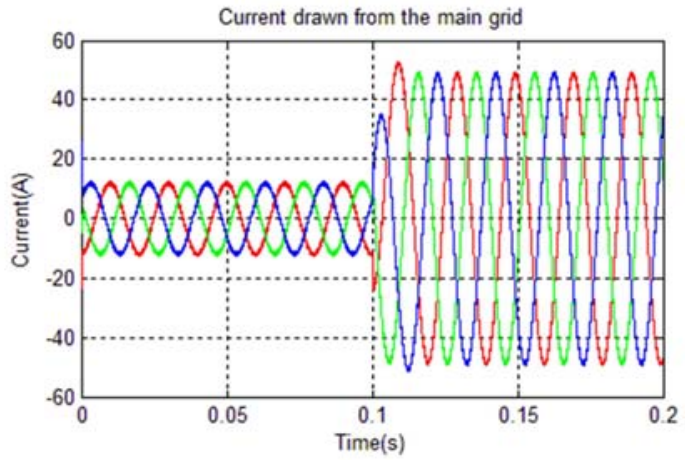

Figure 11(b). Current drawn from the main grid.

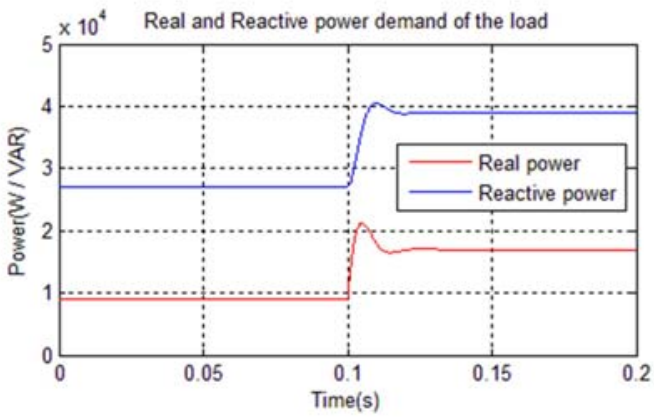

Figure 12(a). Real and reactive power demand of the load

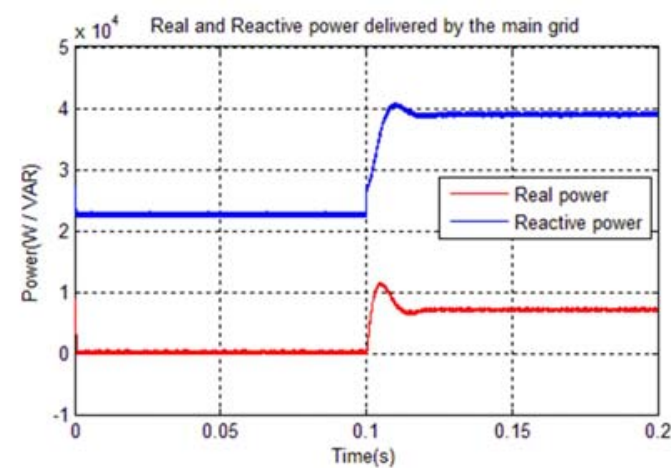

Figure 12(b). Real and reactive power delivered the main grid.

The inverter current waveform and the real and reactive power delivered by the DG source for the three current control techniques are shown in the Figs. 13 and 14, respectively. It can be inferred from the figures that the inverter current and power waveforms of the vector HCC technique are smoother compared to the other two techniques. 


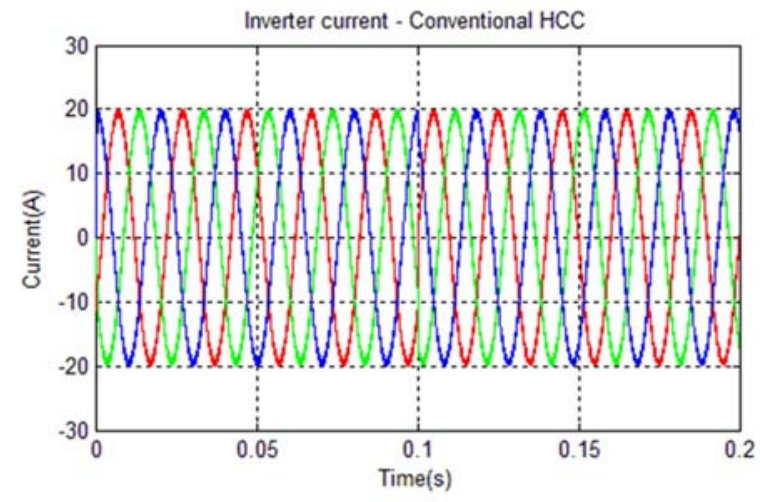

Figure 13(a). Current delivered by the distributed generation (DG) source-conventional hysteresis current

control

(HCC).

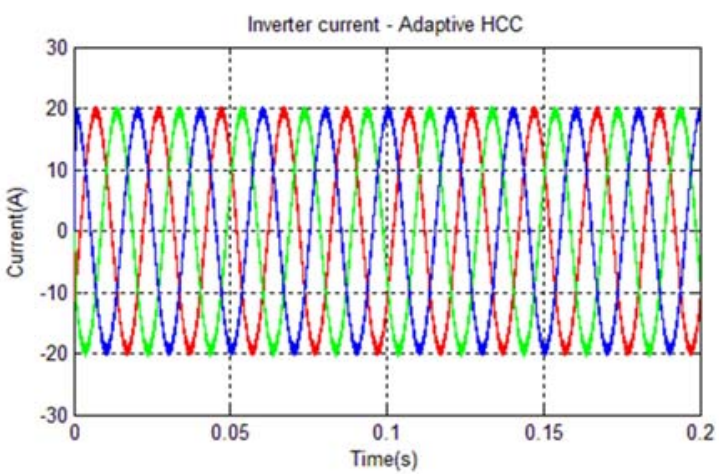

Figure 13(b). Current delivered by the distributed generation (DG) source- Adaptive hysteresis current control (HCC).

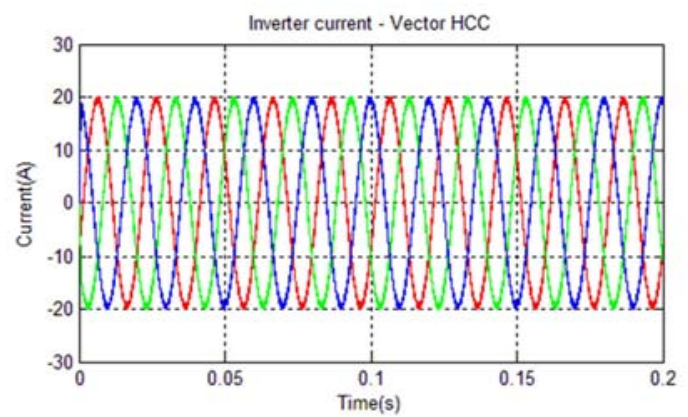

Figure 13(c). Current delivered by the distributed generation (DG) source-vector hysteresis current control (HCC).

Figure 15(a) seems to resemble Fig. 15(b). Figure 16 shows the error bandwidth in the stationary frame. Figure 15 shows that the error band region is more confined and the magnitude of the error vector is restricted in the case of a vector-based technique. Figure 15(b) shows a tuned bandwidth resembling Fig. 7.

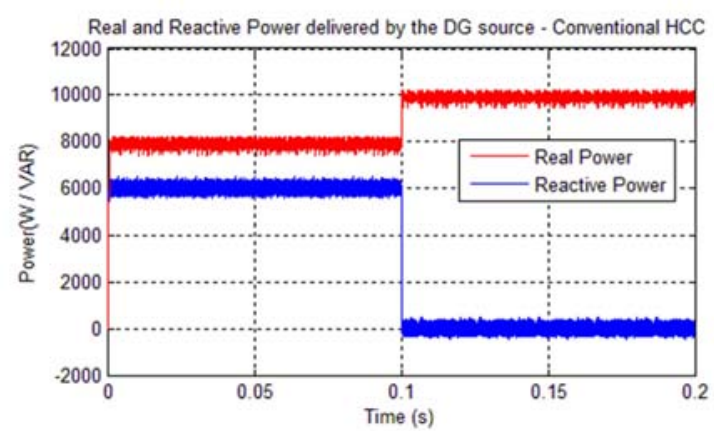

Figure 14(a). Real and reactive power delivered by the distributed generation (DG) sourceconventional hysteresis current control (HCC).

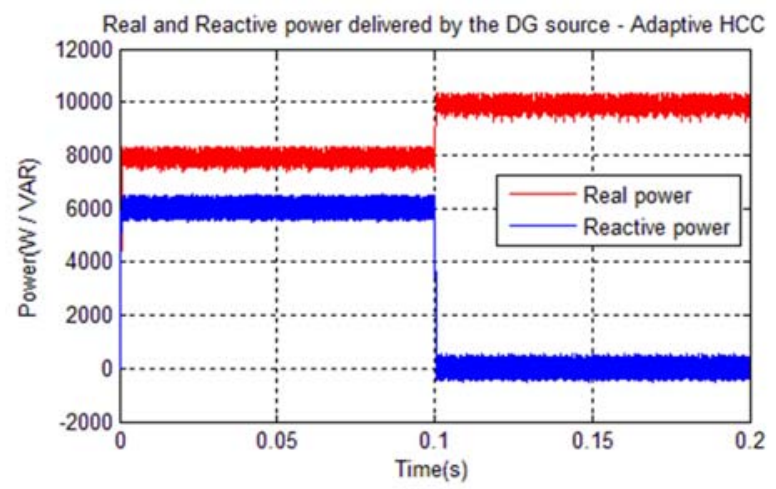

Figure 14(b). Real and reactive power delivered by the distributed generation (DG) source-adaptive hysteresis current control (HCC).

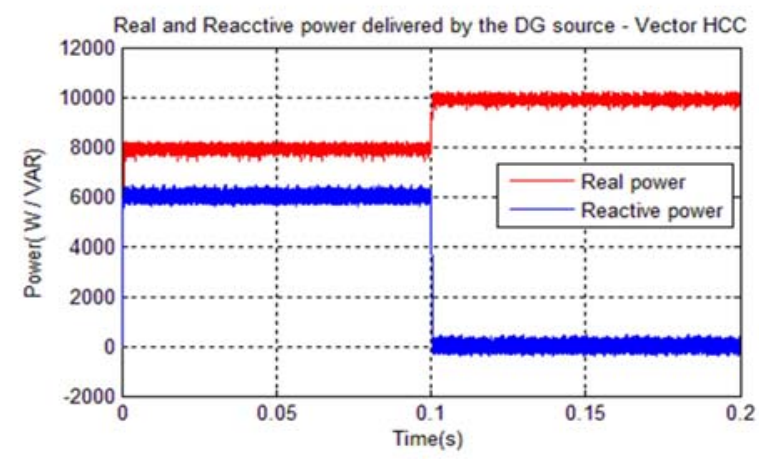

Figure 14(c). Real and reactive power delivered by the distributed generation (DG) source-vector hysteresis current control (HCC). 


\section{Conclusions}

An effective real and reactive power control strategy for the distribution side power injection of a PV DG source has been discussed. This PQ control strategy

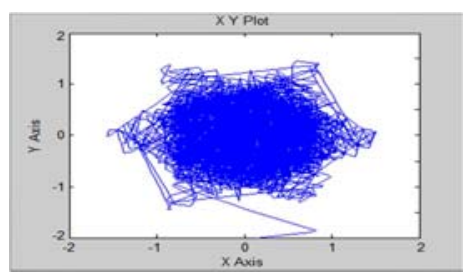

(a)

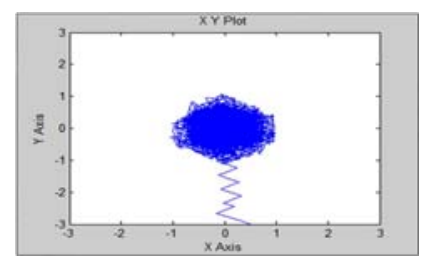

(b)

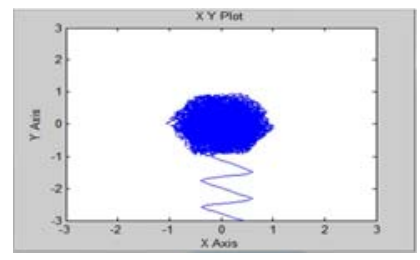

(c)

Figure 15(a). Current error in $\mathrm{dq}$ planeconventional hysteresis current control (HCC), (b) adaptive HCC and (c) vector HCC.

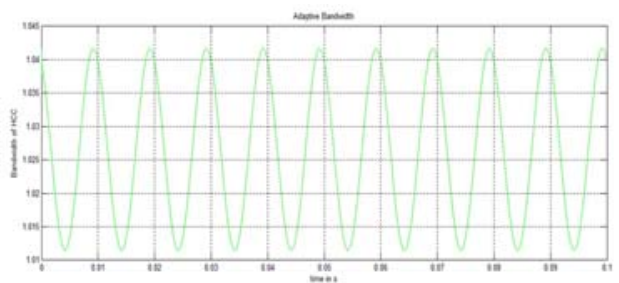

Figure 16. Adaptive band tuning.

Table 3: Comparison of simulation results

\begin{tabular}{lcc}
\hline Parameters & $\begin{array}{l}\text { Switching } \\
\text { loss } \\
\text { (Watts) }\end{array}$ & $\begin{array}{c}\text { THD } \\
\text { of inverter } \\
\text { current (\%) }\end{array}$ \\
\hline Conventional & 170 & 5.4 \\
Adaptive & 130 & 3.2 \\
HCC & & \\
Vector HCC & 60 & 2.1 \\
\hline
\end{tabular}

was executed through a conventional HCC technique. Having observed the disadvantages in implementing a conventional $\mathrm{HCC}$ technique, an adaptively tuned $\mathrm{HCC}$ and a vector-based HCC were employed in the system, Their simulation results were then compared and the system was analysed for the three current control techniques. Based on the observations carried out on parameters such as total harmonic distortion and the switching loss of the system, the vector-based control technique was found to be more appropriate and effective.

\section{References}

Babu D, KN, Ramaprabha R, Rajini V (2012), Mathematical modeling and simulation of grid connected solar photovoltaic system. International Journal of Electrical and Electronics Engineering 20(5):73-77.

Blaabjerg F, Chen Z, Kjaer S (2004), Power electronics as efficient interface in dispersed power generation systems. IEEE Transactions on Power Electronics 19(5):1184-1194.

Brod DM, Novotny DW (1985), Current control techniques of VSI-PWM inverter. IEEE Transactions on Industrial Applications 562570.

Chitti Babu B, Mohapatra M, Jena M, Naik A (2008), Dynamic performance of adaptive hysteresis current controller for mainsconnected inverter system. IEEE Transactions on Power Electronics 22(3):197- 306.

Esram T, Chapman PL (2007), Comparison of photovoltaic array maximum power point tracking techniques. IEEE Transactions on Energy Conversion 22(2):439-449.

Kwon BH, Kim TW, Youn JH (1998), A novel SVM-based hysteresis current controller. IEEE Transactions on Power Electronics 13(2):297307.

Mohseni M, Islam SM (2010), A new vector-based hysteresis current control scheme for threephase PWM voltage-source inverters. IEEE Transactions on Power Electronics 25(9).

Rahim NA, Mekhilef S (2002), Implementation of three-phase grid connected inverter for photovoltaic solar power generation system. Proceedings IEEE PowerCon, 1:570-573. 
Salmi T, Bouzguenda M, Gastli A, Masmoudi A (2012), MATLAB/Simulink-based modelling of solar photovoltaic cell. International Journal of Renewable Energy Research 2(2).

Vahedi H, Sheikholeslami A, Bina MT (2011), A novel hysteresis bandwidth (NHB) calculation to fix the switching frequency employed in active power filter. IEEE Applied Power Electronics Colloquium (IAPEC), 156.

\section{Appendix}

Transmission line parameters:

Resistance: $0.2 \mathrm{ohms} / \mathrm{Km}$

Inductance: $0.5 \mathrm{mH} / \mathrm{Km}$

Transformer rating:11KV/415V

Load parameters:

From 0-0.1 s:

Real power demand: $8000 \mathrm{~W}$

Reactive power demand: 12000 VAR

From 0.1-0.2 s:

Real power demand: $16000 \mathrm{~W}$

Reactive power demand: 24000 VAR

DC link voltage $\left(\mathrm{V}_{\mathrm{dc}}\right): 700 \mathrm{~V}$

Adaptive tuning of hysteresis band:

Line inductance (L): $5 \mathrm{mH}$

Switching frequency $\left(\mathrm{f}_{\mathrm{s}}\right): 12 \mathrm{KHz}$ 